\title{
THE INTERNATIONAL POLITICS OF NUCLEAR WEAPONS: A CONSTRUCTIVIST ANALYSIS
}

\author{
Jo-Ansie van Wyk, Department of Political Sciences \\ University of South Africa \\ and \\ Linda Kinghorn, Hollie Hepburn, Clarence Payne and \\ Chris Sham, Department of Politics and Governance \\ University of Johannesburg
}

\section{Introduction}

Constructivism challenges the prevailing approaches to international relations and security. It attempts to explain, inter alia, how actors acquire their identities, and how these identities shape actors' material and non-material interests. These constructed identities and interests further define mutually constructed rules, norms and institutions, which enable states and other actors to act accordingly. For constructivists, actors approach social facts in terms of the meaning, significance, value and beliefs these actors ascribe to such facts. Once an actor has constructed the social purpose (i.e. its identity and/or interests) of a particular social fact, the actor ascribes new meaning to this fact. The next step for the actor and others would then be to construct social practices based on mutually constructed norms, rules and institutions to engage with this social fact. States, therefore, could have different identities and varying interests at different times (Barnett, 2005:251-270).

In constructivist terminology, the continued prevalence of nuclear weapons and states' dominance in the nuclear arena constitute social facts. These weapons illustrate, among other things, states' commitment to their constructed social purpose, namely maintaining power and prestige (i.e. identity), and dominance (i.e. identity and interests) - despite the possibility of non-state actors' access and application of nuclear technology and weapons.

This article focuses on the continued international politics of nuclear weapons. Our viewpoint is based on the hypothesis that, despite various nonproliferation efforts, nuclear weapons continue to dominate international relations as is evident in the nuclear stand-off between the US and Iran, and North Korea's continued contravention of established norms regarding nuclear weapons. Some reviewers of this article objected to the use of constructivism and proposed an 
application of the regime theory to address the topic at hand. Given the proliferation of regime analyses of nuclear weapons, this contribution especially steers away from regurgitating these analyses by applying the analytical instruments offered by constructivism. In applying a constructivist approach, this article aims to:

- $\quad$ analyse states' constructed meaning of nuclear weapons;

- present an overview of historical and contemporary normative innovation and construction vis-à-vis nuclear weapons;

- $\quad$ analyse a selection of states' construction of their nuclear identity and interest including India, Pakistan, China, North Korea and the US; and

- analyse states' construction and institutionalisation of norms regarding the export of and trade in nuclear weapons and technology.

\section{Constructivism}

The article follows a constructivist approach as espoused by scholars such as Kratochwil (1989), Onuf (1989) Wendt (1992 \& 1995), and Zehfuss (2002). ${ }^{1}$ For constructivists, the roles of rules and norms are important in understanding international relations. For an actor, every action or interaction has to be meaningful. Actors, therefore, continuously construct or reconstruct their identities, interests and interactions. Wendt (1994:384-387; 1995: 71-81) distinguishes three state identities: corporate identity, which refers to a state's intrinsic qualities such as norms, beliefs and resources; social identity (or roles), which consists of a set of meanings that a state attributes to itself; and a state's collective identity, which is established when a social identity generates collective interests. A collective identity manifests in expressions of solidarity, identification with the other's loyalty and concern for the other's welfare.

Constructivism focuses on the power of ideas (as encapsulated in norms, values, rules and principles) in defining ranges of actions and interactions. Furthermore, it focuses on the cyclical relationship between an actor's interests and behaviour, and the social context within which such a relationship exists and operates. Moreover, constructivism argues that actors construct their social contexts of shared values and norms, and that these contexts in turn construct actors' identity and behaviour, which includes actions and interactions (Ba \& Hoffmann, 2003:1533; Barnett, 2005:256-267). To paraphrase Wendt's maxim: anarchy, or order for that matter, is what states and non-state actors make (or unmake) of it. Moreover, constructivists regard the facts of international politics not as a reflection of an objective, material reality but rather as an inter-subjective social reality. What actors do, their interests, and the structures within which they operate are constructed by social norms and ideas, instead of objectives, or material conditions (Barkin, 2003:326).

Ideas and identity play a stronger role in defining interests than material forces (Halabi, 2004:35). Therefore, we explain change in terms of an actor's 
(re)construction of its (an actor's) identity, and the meaning an actor attributes to this identity, which determines an actor's interests and interactions. Furthermore, socalled universal norms are a social construct, just as much as International Law is. The norms of the international system have an innate Western bias. Chinese norms on identity, interests and interactions, for example, are mostly ignored with regard to their international relations in general, and nuclear weapons in particular. Western approaches have a limited understanding of the normative and legalist legacy of, for example, Mencius and Confucius in China's contemporary international relations. The same applies to North Korea, Iran and Japan. Non-state actors with (or without) nuclear weapons also challenge these so-called universal norms.

\section{The idea and meaning of nuclear weapons}

For constructivists, meaning arises, inter alia, from an inter-subjective context based on, and mediated by, rules and norms. These rules and norms shape decisions and lead to (in)action from which a specific meaning is derived (Kratochwil in Zehfuss, 2002:16-17). The decision (based on the norm to establish peace) to use nuclear weapons in WW II shaped what was to come in August 1945. Subsequent to these events, nuclear weapons gained new meaning. This section outlines some of the ideas associated with and meaning(s) ascribed to nuclear weapons.

\section{The memory of Hiroshima and Nagasaki}

Hiroshima and Nagasaki symbolise the darkest side of humankind in a war situation. Subsequently, nuclear non-proliferation should be an absolute priority to prevent similar apocalyptic events in future.

Concerning the idea and meaning of the application of nuclear technology, Japan is a special case as Japan's Prime Minister, Junichiro Koizumi (2004:1-2) stated (note the constructivist interpretations added in italics by the authors):

As the only nation (identity) in human history to be bombed with atomic weapons (reality), Japan has complied with its peace constitution and firmly maintained the Three Non-Nuclear Principles (ideas), with their strong commitment (interests) not to repeat the tragedy of Hiroshima and Nagasaki (meaning). Japan will continue to pursue this stance, and lead the international community to promote nuclear disarmament and nuclear nonproliferation (action) and devote itself to abolish nuclear weapons (meaning and change) through its enhancement of efforts to call on governments for early ratification of the Comprehensive Nuclear Test Ban Treaty (CTBT) (interaction and change).

Since 1945, there has been no change in this position of the government of Japan as successive cabinets have repeatedly articulated the so-called Three NonNuclear Principles, which is "the policy of not possessing, not producing and not permitting the introduction of nuclear weapons into Japan”. Ratifying the Non- 
Proliferation Treaty (NPT) in 1976, Japan has placed itself "under obligation as a non-nuclear weapons state not to produce or acquire nuclear weapons”, "nuclear activities (are) to be conducted only for peaceful purposes”, and "Japan has no intent to possess nuclear weapons” (MOFA, 2005a:1). Japan remains actively involved in disarmament and non-proliferation issues and organisations. A signatory to most of the non-proliferation treaties, Japan assists the denuclearisation processes in Russia, Ukraine, Kazakhstan and Belarus (MOFA, 2004:116-125).

\section{Absolute and revolutionary weapon}

As the events of August 1945 indicated, the effect and application of nuclear weapons is total, non-discriminate devastation, which left an indelible psychological mark on humankind - even more than the recent 9/11 event in the US.

\section{A new source of (in)security}

States maintain and enhance their security and sovereignty by acquiring weapons and therefore continue to seek nuclear weapons for their strategic importance, as a deterrent and as instruments to win wars. Arms thus provide states with an assurance of their survival. Pakistan's nuclear programme, for example, emanates from that country's insecurity as regards India, while India's programme is a response to its insecurity as regards China (Russett, Starr \& Kinsella, 2006:231, 243-244). Moreover, when states enter into any international agreement, a reconstruction of their identity, behaviour, relations and expectations occurs. Most states, nevertheless, comply with these agreements because the agreements ensure the countries' security and advance their interests.

\section{A new source of authority, power, influence and prestige}

Nuclear technology and its military application marked a major turning point in international relations, and the conduct of war. For states, nuclear technology remains a status symbol, which distinguishes countries that have such weapons from those that do not. The development of nuclear weapons requires a very sophisticated and highly developed scientific community, an asset not every country has or can afford. Nuclear technology has also added a form of political and technological determinism in international affairs (Howlett, 2005:508). Once a state has acquired nuclear technology, it is likely to develop it via a dedicated nuclear programme, conduct tests, produce weapons, stockpile such weapons and, in a worst-case scenario, employ these weapons.

\section{Normative innovation and a new taboo}

States owe their existence to one of the single most important ideas in international relations and International Law, namely that of sovereign equality as espoused in the UN Charter. This idea has become one of the norms regulating international relations and International Law.

UN members established a universal norm when they adopted resolutions and conventions against the development, stockpiling and use of nuclear weapons. One of the fundamental norms of International Law is pacta sunt servanda (treaties 
are to be obeyed) (Chayes \& Handler Chayes, 1993:185). Norms provide, inter alia, motivations for and methods of action. International cooperation is an essential element required in order for non-proliferation to succeed as no single state, or small group of states, can effectively eliminate proliferation. Participating states have to agree on non-proliferation and should be prepared to relinquish their freedom to act independently. It is, however, a difficult task as advocating transparency, openness and unanimity can clash with national security and state information. An important method to decrease the proliferation of nuclear weapons is to lessen the motivation for requiring these weapons, whilst raising the costs. Containing proliferation has proven to be problematic recently as international law is seldom enforced (Janis in Pogany, 1987:53).

\section{The application of nuclear technology for global development}

The International Atomic Energy Agency (IAEA) regularly outlines the civilian application of nuclear technology in the food and agricultural, water, energy and human health sectors, as well as for the protection of marine and territorial environments (IAEA, 2005a:1339).

\section{Export and trade regimes}

Nuclear technology has become available to more actors, and it has become lucrative to sell technology, expertise or equipment to those actors wanting to acquire it. This causes more proliferation, and in order to prevent this, normative innovation has occurred with the establishment of export and trade norms.

\section{New politics and a new nuclear order}

Nuclear technology and weapons changed diplomatic practices during and since the end of the Cold War. Proliferation has become more dynamic and complex than ever before. Today, states and non-state actors are motivated by a variety of reasons, or constructions, to acquire nuclear technology and weapons. These are ideology, domestic political factors, and encouragements from a sophisticated scientific community, deterring and preventing intervention by a neighbouring and/or other actor, domestic and diplomatic bargaining, and a state's threat perception. Another complexity arises when some states (such as South Africa and Libya) de-construct their nuclear identity and interests by voluntarily "de-nuking”, or dismantling their nuclear weapons programme and/or their civilian application of nuclear technology (as in the case of Germany) (Howlett, 2005:509).

\section{New actors}

The possibility that so-called "terrorist networks" may acquire nuclear technology, and that other non-state actors have acquired such technology and use it for political purposes has given rise to serious concerns. Subsequently, normative innovations are emerging in this regard. 


\section{Constructing norms pertaining to nuclear weapons}

The US (since 1945), the USSR (since 1949), the UK (since 1952), France (since 1960) and China (since 1964) have successfully tested nuclear devices. The impact of uncontrolled proliferation compelled the US, the USSR and the UK mainly, to consider strategies to curb horizontal and vertical proliferation. One of these strategies was the establishment of norms. Since the 1940s, four phases, namely normative emergence, innovation, construction and consolidation can be distinguished (adapted from Van Vuuren, 2003:112-147).

During the first phase (1945-1970), disarmament, the elimination and control of nuclear weapons were established as norms. On 24 January 1946, the UN General Assembly adopted a resolution that called for the elimination of all major weapons of mass destruction. Subsequently, these norms evolved into the establishment of the IAEA and the signing of the Non-Proliferation Treaty (NPT). Signed in 1968, the NPT only became enforceable in 1970. In Article IX, the NPT defines a nuclear weapon state (NWS) as "a state that had manufactured and exploded a nuclear weapon or other nuclear explosive device before 1 January 1967" (NPT in Goldblat, 1985:247-250). Nuclear weapon states include the US, the former USSR, France and China. States that subsequently acquired nuclear technology and weapons continue to be regarded as so-called "non-nuclear weapon states" (NNWS). Marked by inconsistencies, the NPT constructed strange "nuclear orders” during and after the Cold War (Walker, 2004). France and China, for example, UN Security Council members and NWS ratified the NPT in 1992 only. Israel, for example, has nuclear weapons and is one of a few UN members that have not signed the NPT. Only three UN members (Israel, Pakistan and India) have not signed it yet. North Korea withdrew from the treaty in 2003.

The NPT represents the only binding commitment by the NWS to nuclear disarmament. It also aims to enable NNWS to feel secure in a nuclear environment, to promote the peaceful manufacturing of nuclear energy, and to persuade states, through negotiations, to conform to non-proliferation. The NPT also prescribes the behaviour of NNWS party to the Treaty. Non-nuclear weapons states:

- have to submit their civilian nuclear programmes to IAEA safeguards;

- $\quad$ cannot receive or transfer nuclear weapons or other nuclear explosive devices;

- cannot control such weapons or explosive devices directly or indirectly;

- cannot manufacture or otherwise acquire nuclear weapons or other nuclear explosive devices; and

- $\quad$ cannot seek or receive any assistance in the manufacturing of nuclear weapons or other nuclear explosive devices (Mutimer, 2000:2-3). 
Despite the development and stockpiling of nuclear weapons by the NWSs, as well as their Cold War standoffs, the NPT has been one of the most successful attempts at nuclear disarmament and non-proliferation. More countries have ratified the NPT than any other agreement, a testament to the Treaty's significance. Some of the Treaty's post-Cold War successes include South Africa, Brazil, Libya and Argentina dismantling their nuclear weapons facilities, and their accession (together with France, China and Cuba) to the NPT.

The collapse of the USSR posed a proliferation risk. However, by 1994, former USSR republics such as Kazakhstan, Belarus and Ukraine transferred their nuclear weapons to Russia and acceded to the NPT. In constructivist terms, the NPT established an unprecedented normative structure, which constrains actors in terms of their nuclear capability, and prescribes their behaviour in these areas. In effect it de-legitimised the acquisition of nuclear weapons by additional countries (Klare \& Chandrani, 1998:138).

The second phase (1971-1990) is significant as most of the nuclear arms limitation talks and agreements (such as SALT I and II, the ABM Treaty, the INF Treaty and START) between the US and USSR occurred during this phase. This phase was characterised by growing support for the NPT as more states became party to it. Additional norms, such as security assurances, verification, export control, the protection of nuclear material and compliance, were established. Another normative approach to end the proliferation of nuclear weapons was the establishment of some of the first nuclear weapons-free zones (NWFZs). Established by an international agreement, NWFZs prohibit states to manufacture, acquire, possess, deploy or control nuclear weapons. Furthermore, it obliges all NWSs not to use nuclear weapons against states in these zones. Today, Europe, North America, the Middle East and Eurasia are not included in any NWFZ - regions mainly dominated by nuclear weapons states such as the US, the UK, France, Russia and China. NWFZ treaties operate in Latin America and the Caribbean (The Treaty of Tlatelolco, 1968) and the South Pacific (The Treaty of Rarontonga, 1986). Subsequently South-East Asia (The Treaty of Bangkok, 1997) and Africa (The Treaty of Pelindaba) established NWFZs. Antarctica, outer space, the moon and the seabed are also designated NWFZs (MOFA, 2004:126-134).

As more states developed nuclear (military or civilian) capacities during the Cold War, and as more gained access to these resources, it became imperative to harmonise the supply of and trade in nuclear technology and material with international norms and International Law. Although there are states that can legitimately produce nuclear energy, it is extremely difficult to contain the transfer of technology and materials. Not all states are careful custodians of these materials (Wirtz, 2003:391). More importantly, some states as well as non-state actors are at times beyond the reach of International Law, diplomatic incentives and inducements, and multilateralism. They prefer to defy the global community instead of participating and cooperating in order to solve security issues. 
The third phase (1991 and 2000) saw the institutionalisation of nonproliferation norms, during which actors responded to new nuclear issues and actors. By 1991, the USSR collapsed and its successor states raised significant proliferation and security concerns.

The 1991 Gulf War was the first international conflict since the end of the Cold War. It exposed Iraq's nuclear and Weapons of Mass Destruction (WMD) programme, as well as some of the limitations of the non-proliferation efforts. Iraq, a Charter member of the NPT when it entered into force in 1970, used its oil wealth to acquire nuclear technology and capabilities in the 1970s. After Israel had destroyed the Osirak reactor, Iraq developed a clandestine nuclear weapons programme separately from its declared nuclear activities and facilities. Frequent IAEA inspections were unable to detect these, and the scope of the programme only became evident after the Gulf War (Klare and Chandrani, 1998:143). As Iraq was in violation of the NPT and IAEA regulations, the UN Security Council ordered the IAEA to confiscate, remove, destroy or render harmless Iraq's nuclear weapons capabilities. By 1998, these inspections confirmed the reduction of Iraq's nuclear and WMD capabilities. Subsequently, Iraq suspended cooperation with the UN and forced the IAEA to withdraw from Iraq.

The fourth phase (since 2001) covers developments since the events of 9/11, especially the role of the US as norm entrepreneur and its ability to construct the UN agenda on nuclear weapons. Undergoing significant changes in its social and collective identity, the US constructed its new global interests when President Bush declared war on terrorism by his identification of an "axis of evil”, and the US's subsequent invasion of Afghanistan and Iraq. Acting as a norm entrepreneur, the US succeeded in convincing a critical mass of states to embrace new norms vis-à-vis terrorism and the country's use of nuclear technology. The US was successful in its efforts to "create" the threat of nuclear weapons and WMDs in Iraq, and in establishing a "coalition of the willing" (to further its interests), during which these US norms cascade through to other actors and the global security agenda. This cascade and institutionalisation of these norms are illustrated in states' signing of the UN's International Convention for the Suppression of Acts of Nuclear Terrorism in 2005. States party to this Convention expressed their concern "about the worldwide escalation of acts of terrorism" and about the fact that "acts of nuclear terrorism may result in the gravest consequences and may pose a threat to international peace and security” (UN, 2005:1).

By 2007, the US was instrumental in constructing and institutionalising new meaning and norms relating to nuclear weapons, such as the establishment of the Proliferation Security Initiative (PSI) and the Global Threat Reduction Initiative (GTRI). Coalition construction and norm entrepreneurship by the US contradict some of its own actions and non-proliferation commitments, and indicate a selective adherence to normative aspects of nuclear weapons. The US has, for example, not ratified the Comprehensive Nuclear Test Ban Treaty (CTBT), but tolerated Israel's nuclear activities outside the NPT. US support for the NPT stems from its usefulness 
to dismantle, for example, Russia’s nuclear weapons (Bunn \& Wier, 2005). The US's economic aid and other incentives played a major role in eliminating the nuclear weapons stocks of the USSR's former republics, such as Ukraine, Belarus and Kazakhstan, that became independent after the end of the Cold War. American engagement, diplomacy and incentives were also instrumental in ending proliferation in Brazil, Taiwan, Argentina, South Africa, Sweden, Austria and South Korea (Newnham, 2004:165).

This fourth phase also poses a significant challenge to the UN. With its corporate and social identity rooted in the Charter, the UN (as an inter-governmental organisation comprising members with conflicting identities and competing interests) plays an important role in norm innovation, norm cascading, institutionalisation and enforcement - especially regarding nuclear weapons. Its specialised agencies, the IEAA and the Preparatory Commission for the Comprehensive Nuclear Test Ban Treaty Organisation (CTBTO PrepCom), strive to eradicate nuclear weapons. These agencies cooperate to accomplish permanent and unchallenged non-proliferation, and their achievements are evident in the treaties and agreements endorsed by member states. A renewed commitment to the total elimination of nuclear weapons was expressed at the $60^{\text {th }}$ General Assembly (GA) in 2005. The GA statement also stated "[t]hat every effort should be made to avoid nuclear war and nuclear terrorism” (MOFA, 2005b:1-3).

Another concern for the UN is the fact that states cannot be forced to sign any international conventions or treaties pertaining to the non-proliferation of nuclear weapons and technology. As North Korea and Iran recently demonstrated, states cannot be compelled to remain involved in these treaties and conventions. States that are not members of the NPT and/or do not adhere to safeguarded nuclear activities are potentially very dangerous. After 9/11, the US constructed these states an "axis of evil", which include North Korea, Syria, Iraq and Iran (Kegley \& Wittkopf, 2004:507).

\section{The role of social facts and inter-subjective realities: India and Pakistan}

This section reviews India and Pakistan's construction of realities, identities and nuclear norms. Two social facts dominate India and Pakistan's position with regard to nuclear weapons.

Firstly, geo-political realities determine India and Pakistan's construction of norms regarding nuclear weapons. These countries' security policies are driven by the shared goal of being recognised as the dominant power in the region, and their drive to maintain their social identity. Both constructed inter-subjective realities, i.e. their uneasiness regarding China's nuclear weapons and missile delivery programmes. In 1964, Atal Bihari Vajpayee, the then Indian Prime Minister, stated that "the answer to an atom bomb is an atomic bomb, nothing else" (Hu, 2000:28-36). In response to China's test, India first tested nuclear weapons in 1974 (the so-called Smiling Buddha Test) and, in 1997, it deployed its own medium- 
range missile. In 1998, five more tests followed under Operation Shakti (Klare \& Chandrani, 1998:141; Hu, 2000:28-36). By 1999, the Indian government constructed the objectives, deployment, and the control and composition of its nuclear weapons. In India's nuclear doctrine, the government of India states that its rationale for nuclear weapons is that it "remain(s) instruments for national and collective security” (Thomas, 2002:181-184). India continues to maintain that no decision has been reached to build a nuclear arsenal. By 2002, unofficial estimates on India's stockpile range between 30 and 35 nuclear warheads. Furthermore, India is estimated to have produced enough weapons-grade plutonium for 50-90 nuclear weapons and a smaller but unknown quantity of weapons-grade uranium produced at the Bhabha Atomic Research Center (Federation of American Scientists, 2002:1).

Pakistan's ability to manufacture nuclear weapons is chiefly attributed to the aid received from China. Pakistan's formidable nuclear status is due to Abdul Qadeer Khan's facilitation of its nuclear weapon programme. Considered "the father of Pakistan's bomb”, Khan was hailed as a national hero. Believing that he was assisting the Islamic nation's rise to glory, Khan subsequently sold nuclear technology to various countries (including North Korea, South Africa and Iran), adding to horizontal proliferation.

Pakistan conducted its first fission tests in 1998. However, in terms of the NPT, Pakistan is not supposed to be in possession of nuclear arms. The US's attempts to persuade Pakistan not to produce weapons-grade enrichment uranium failed. Pakistan's concentration is on weapons technology, particularly the production of highly enriched uranium suitable for nuclear weapons. In 1990, the US Administration cut off aid to that country because it was unable to certify that Pakistan was not pursuing a policy of manufacturing nuclear weapons, which was reviewed and subsequently relaxed in 2001. However, in the wake of 9/11 the American position on Pakistan changed. The IISS (2005:13) mentions the “pragmatic American tolerance” for President Musharraf's undemocratic regime, as well as economic and military awards amounting to US\$ 3 billion to Pakistan for its role in the war on terrorism.

Secondly, both India and Pakistan have a history of conflict amongst themselves. Each of these countries constructed an inter-subjective reality, i.e. a possible nuclear attack by the other. This determines their action and interaction with one another. For Pakistan, India's possession of a nuclear weapons capability, its development of short- and intermediate-range missiles and, since their partition in 1947, its defeat by India in a number of wars, constitute grave social facts. The rivalry between these states pushed both to a stance where neither one will actively promote disarmament or support the NPT. Both states have refrained from signing the NPT. Here, political tensions and proliferation are determined by divergent constructions of identities, interests and inter-subjective realities. This results in no cooperation between these states, or IAEA inspections and verification. This exposes the shortcomings of the non-proliferation initiatives as, for example, India continues to develop its nuclear programmes. India's critique of the NPT is that it 
should be implemented as a mechanism for ensuring complete "disarmament" (Klare \& Chandrani, 1998:142; Mutiner, 2000:103).

\section{Constructed identity: The case of North Korea}

The North Korean state is based on the so-called Juche idea, which means that the state will maintain its Chajusong (independence) through self-reliance. This corporate identity with a superimposed social identity (independence and selfreliance) of North Korea continuously constructs its interests and interactions. Since the Korean War, it has constructed its identity as that of a "socialist paradise", based on "democratic centralism", and, in terms of the construction of its interests, on protecting its people against the US, which it regards as a country of "western barbarians" and as an "imperialist". ${ }^{2}$ North Korea has taken these and other intersubjective realities and social facts as the basis for the development of its nuclear programme. In this way, North Korea was able to prove to the international community that the country is worthy of respect and an actor to be reckoned with. Moreover, in this way it gave meaning to its so called Three Revolutions (i.e. ideological, technical and cultural revolutions).

For more than a decade, the US and North Korea have been engaged in nuclear stand-offs (Howard, 2004:805-828). These originated from Pyongyang's announcement in December 2002 that it had reactivated its nuclear reactor at Yongbyon. Efforts by the IAEA to assess North Korea's nuclear installations and capabilities were stunted when the government threw the IAEA out of the country. By early 2003, the IAEA announced that it found North Korea in breach of internationally agreed-upon nuclear safeguards, as well as of the principles, rules and regulations of the NPT of which the country is a member (BBC World Online, 2005). In January 2003, North Korea withdrew completely from the NPT, which it signed in 1985 (Wittkopf, Kegley \& Scott, 2003:63). This particular case study is indicative of not only North Korea's reconstruction of its identity and interests and its preferred inter/non-action with the international community, but also of the shortcomings of the non-proliferation initiatives, and thus there is no way to force Korea to be subject to various inspections. Another move that threatened North Korea's security, was South Korea's announcement in 2004 that it had been enriching small amounts of uranium since 2000. At the time, the North Korean government stated that its nuclear weapons "serve as a deterrent against increasing US nuclear threats" (Human Rights Watch, 2005). During this stage, trade sanctions were ineffective in persuading North Korea to end its nuclear weapon programme, as the state's economy was extremely weak. North Korea only decided to discontinue its nuclear weapons programme when the United States of America offered energy-related assistance. In spite of this 'agreement', North Korea continued to produce and test nuclear technology.

Although North Korea has always been suspected of producing nuclear weapons, it still came as a global shock when Kim Jong II admitted, in February 2005, that North Korea had built nuclear weapons, had already spent 8000 fuel rods 
completely, and that the main motivation for North Korea's perusal of nuclear weapons was "self-defence". This, once again, illustrates the power of the intersubjective realities and social facts as Kim Jong II felt threatened by the US, and believed that it (the US) wanted a regime change in North Korea. Subsequently, a series of Six Party Talks (including the US, North Korea, Russia, Japan, China and South Korea) ensued. In September 2005, North Korea agreed to terminate all its nuclear activities and to rejoin the NPT. However, merely a day later (20 September 2005), it undermined the agreement by announcing that it would not scrap its programme until it was given a civilian nuclear reactor (BBC World Online, 2005) in return.

\section{More on identity, norms and meaning: Pax Sinica and "Chinese characteristics”}

Like North Korea, China has a unique social and corporate identity and remains, to some extent, a foreign country. Officially a Marxist-Leninist-Maoist state, China "belongs to the world, but at the same time, it has a political and cultural tradition distinct from the West owing to its unique and long history” (Geeraerts \& Jing, 2001: 264). Deng Xiaoping's use of the term "Chinese characteristics” (in constructivist terms, a construction of China's identity and norms) in 1992 soon became a catch-all phrase for some of China's post-Cold War politics. Deng's "Four Modernisations” (once again a construction of identity, norms and interest) and his reform on socialism to one with "Chinese characteristics" opened China to the world, and vice versa. It was during this phase that China acceded to the NPT in 1992.

China's recent global leap is altering regional and global geopolitics, and uncertainties remain about China's capabilities and intentions. All of these and other factors make China a state not to estrange. The US realises this economically (China enjoys a "most favoured nation" status) and militarily (China is a permanent member of the UN Security Council). More importantly, China is a nuclear power and it has assisted the US in its diplomatic endeavours to disarm North Korea (Cox, 1998:224-245; Albrecht, 2000:129).

There is no consensus on the scope of China's nuclear weaponry. China has been researching and developing nuclear technology since 1953, and was primarily aided by the then USSR. Despite the USSR's withdrawal of its advisors to China, the Chinese continued to manufacture nuclear weapons in order to "break the superpowers' monopoly on nuclear weapons" and conducted its first nuclear test in 1964. This strengthened China against threats posed by US and the USSR, and fortified China's international power and reputation. Chinese authorities have always claimed that their stockpile is to serve as a deterrent for nuclear and conventional attacks, and that China abides by the no first-use pledge. However, China will retaliate against a nuclear attack with a counter-value strike, thus meaning that nuclear weapons will be used against an enemy's most valued non- 
military resources, such as civilians and industries situated in cities (Kegley \& Wittkopf, 2004:503).

Since the end of World War II and, more explicitly, since the end of the Cold War, China's domestic political order, as well as its status as a major power has undergone various reconstructions. China's integration into the Westphalia order had not been easy (Zhang, 2001:63). Today, China is a member of the UN Security Council and the World Trade Organisation (WTO) and an emerging economic giant. It continues to challenge normative aspects (such as human rights and democratisation) of the global order and is still amidst its "Third Great Transformation” of international relations. Lucian Pye (in Zhang, 2001:63) states, “... China is not just another nation state in the family of nations. China is a civilisation pretending to be a state.”

China is emerging as one of the largest users of nuclear energy. By 2005, China had 10 nuclear reactors operating, two under construction and a further six planned (WNA, 2005:1). China is not a global norm entrepreneur, but continues to yield tremendous power through the construction of its norms, identity and interests.

\section{The US's (re)construction of its identity, interests and a "smoking gun"}

A state sustains or transforms its identity and interests within the context of its interactions, and its construction of reality (Widmaier, 2004:436). One of the ideas originating from the White House since 9/11 emanate from the US's construction of an inter-subjective reality, namely that the US is under tremendous threat. This manifested in the construction of the "Bush Doctrine". This construction is illustrated by the US's norms (the right to defend itself), its actions (by preemptive strikes against states and non-state actors), its social and collective identity (to protect all so-called peace-loving nations against states supporting and/or harbouring terrorists), and as a normative entrepreneur in its declaration of a "war on terrorism” (Dombrowski \& Payne, 2003:395-408). In March 2002, the Bush administration announced that it intended to use its nuclear weapons to deter a “nuclear-armed enemy”. Bush’s former Secretary of Defence, Donald Rumsfeld, added, "Terrorist networks have relations with terrorist states that have weapons of mass destruction and they will get their hands on them” (Kegley \& Wittkopf, 2004:465-507).

Early signs of a (re)construction of identity often manifest in speech acts. These speech acts have normative consequences because they have the potential to define, or change, a particular situation or condition (Zehfuss, 2002:171). Examples of speech acts include policy statements, propaganda, threats, ultimatums, justifications, rationales and explanations. In the case of terrorism and the possibility of global leaders' use of nuclear weapons, speech acts include normative statements by such leaders as well as their almost unanimous condemnation of terrorism. Largio (2004:1-3) identified 21 such speech acts by George Bush and his closest circle (including Dick Cheney, John McCain, Donald Rumsfeld, Condoleeza Rice and 
Paul Wolfowitz) before the US-led coalition invaded Iraq. Some of these link directly with the US's post-9/11 identity.

With regard to its social identity and roles vis-à-vis nuclear weapons, the US's ambitions, entitlements and power are evident: commander-in-chief of the war on (nuclear) terrorism, liberator, protector, peacemaker and the harbinger of liberal democracy (via regime change) and free markets.

A constructed collective identity gives social facts meaning and gives such facts a normative force. The US's constructed collective identity gives the US a global role, namely to prevent the proliferation of nuclear weapons by -

- $\quad$ concluding the 1991 Gulf War by invading Iraq in 2003;

- $\quad$ supporting the UN to preserve global peace;

- $\quad$ transforming the Middle East, and

- the fact that history calls the US to action (Largio, 2004:1-2; Farer, 2004:226).

The constructed collective identity of the US also resulted in demonising terrorism around the globe, and in supporting its cause against terrorists. This also manifested in statements such as that terrorism and nuclear weapons remain threats to "all peace-loving nations", and that the US will assist all states threatened by terrorist groups (Largio, 2004:1-3).

A poignant example of the way the US has reconstructed its identity, reality and interests is to be found in the events leading up to the Iraq War. The US interpreted certain principles, norms and rules differently from what is universally accepted and agreed. The US's intervention in Iraq in March 2003 was strongly based on the US's interpretation of the international legal principles such as "use of force”, "pre-emptive strike”, "preventive war" and "anticipatory self defence” but was actually in breach of the International Law (Kegley \& Raymond, 2003:385394). Vagts (2001:843-848) asserts that a hegemon can interpret international law and international customary law differently from other actors. This was clearly illustrated in the US's and UK's efforts to find (or rather, construct the existence of) nuclear weapons and WMDs in Saddam Hussein's Iraq. On September 24, 2002, the British Government issued a 53-page report, Iraq's Weapons of Mass Destruction: the Assessment of the British Government. This report outlined, inter alia, the extent of Iraq's WMDs and the fact that Saddam Hussein could launch these within 45 minutes against both British and American targets. In February 2003, Colin Powell (the then US Secretary of State) gave an elaborate and impressive presentation of what the US regarded as Iraq's WMDs and Saddam Hussein's intentions. Seeking UN Security Council support for an invasion into Iraq, the US, at the time, regarded (or constructed) Iraq's capabilities as "a looming and increasing threat to the world" (Regan, 2004:8). 
Despite several inspections by Hans Blix’s IAEA team, no such weapons were found and on March 19, 2003, without Security Council endorsement, the US, the UK and a so-called "coalition of the willing” invaded Iraq - having constructed evidence of a "smoking gun” and the threat posed by Saddam Hussein. The Iraqi invasion, dubiously called Operation Iraqi Freedom, remains controversial. It is even regarded as illegal, since the IAEA and the Iraq Survey Group, amongst others, found no nuclear weapons and WMDs. ${ }^{3}$ A series of carefully constructed speech acts by George Bush to justify the invasion followed. Their message was that the invasion would bring freedom to the Iraqi people and that it would liberate them from Saddam Hussein's repressive regime (Frederking, Artime \& Sanchez Pagano, 2005:135-151).

\section{Nukes' bazaar? Norms and rules on nuclear export control and trade}

Actors' construction of reality determines such actors' identity, interests and actions. These actions are limited or enhanced by rules. An action, such as the control of trade in nuclear material, weapons and technology, depends on the institutionalisation of rules pertaining to the norm of nuclear non-proliferation. Kratochwil (1989) distinguished between regulative and constitutive rules. The former regulate existing activities, whereas the latter create the possibility for these activities. The NPT, for example, contains regulative rules, whereas, the Nuclear Suppliers Group (NSG) and the Zangger Committee provides constitutive rules.

Initiated to review procedures for exports of nuclear material and equipment related to NPT commitments, the Zangger Committee (a voluntary organisation existing of 31 members) is one of five supplier groups responsible for controlling the supply, transport and shipment of nuclear weapons. Efforts to reign in India (as the first Third World country to join the nuclear club) and France (not a signatory to the NPT) culminated in the establishment of the London Group or London Suppliers Group (now called the Nuclear Suppliers Group, NSG) in 1978. The NSG was one of the first (mainly Western) attempts to institutionalise stringent international norms to guide and control exports of nuclear weapons. Central to the functioning of the NSG was a set of export guidelines, the so-called London Guidelines, which set norms for the export of items used for nuclear energy and related activities, as well as “dual-use goods” (Mutimer 2000:60).

A recent effort to introduce an additional constitutive rule is George W. Bush's establishment of the Proliferation Security Initiative (PSI) in May 2003. The US-led PSI aims to prevent and decrease the illegal trafficking of and trading in nuclear weapons and their delivery systems. More than 60 states are members of the PSI. Despite the US's pressure, China, India and Indonesia, where some trafficking occurs, oppose the PSI. In May 2004, the US institutionalised another constitutive rule when it established the Global Threat Reduction Initiative (GTRI) "to identify, secure and recover high risk vulnerable nuclear and radiological materials around the world" and to reduce the threat of nuclear terrorism. The GTRI will attempt to minimise the amount of nuclear material available globally. The GTRI is very active 
in the Soviet successor states and, with the assistance of the IAEA, it has transferred nuclear material, fuel and equipment from the Czech Republic, Romania, Serbia, Montenegro, Bulgaria, Uzbekistan and Latvia to Russia (IAEA, 2005c:1).

\section{Einstein's warning: non-state actors and nuclear weapons}

In a letter to Sigmund Freud in 1932, Albert Einstein wrote:

I have so far been speaking only of wars between nations; what are known as international conflicts. But I am well aware that the aggressive instinct operates under other forms and in other circumstances (Calaprice, 2005:384).

The US's war on terrorism is reminiscent of Einstein's warning. In October 2005, MI5 released a document, Companies and Organisations of Proliferation Concern, which identified more than 360 private companies, university departments and government departments in eight countries, as well as the Pakistani High Commission in the UK, as having procured material and technology for use in weapons programmes. MI5 warned of exports to organisations in Iran, Pakistan, Israel, Syria and Egypt. Furthermore, it identified the United Arab Emirates (UAE) as “an arms trade supermarket”. Moreover, 95 Pakistani, 114 Iranian, 11 Israeli and 73 Indian organisations were identified as assisting in their countries' weapons programme. Some 24 private UAE firms have been identified as having acquired nuclear and other WMDs technology for Iran, Pakistan and India (The Guardian, 2005: 1).

For constructivists, the issues of terrorists (as non-state actors) and their potential to use nuclear weapons centre on possibilities, access, identity, ideas and meanings, the construction of a certain reality, how change can be achieved, or how a certain idea such as an Islamist order or peace and stability, can be achieved. Internationally, the proliferation of nuclear weapons promotes the availability of nuclear devices for possible use by so-called terrorist groups. Despite predictions by some that terrorist organisations, such as Osama bin Laden's Al Qaeda, HAMAS and others could use nuclear weapons and WMDs to cause death and destruction, it has not been the case so far. The Report of the Policy Working Group on the United Nations and Terrorism (UN, 2002:9) concluded that there is "no reliable assessment of the quantity and quality, dual use and related materials, devices and technologies in the possession of groups and individuals associated with terrorism”.

However, states' construction of inter-subjective realties, namely that socalled terrorist groups intend to use these weapons, constitutes the basis of state actions. Added to this is the social fact that some of the main sources of nuclear weapons and fissile material are in Russia, lying in unsecured sites such as nuclearwaste depositories. Attempts to secure Russia's nuclear weapons and fissile material can only be carried out by the year 2020. This is a major concern for many countries 
as these locations are susceptible to theft and they remain easy targets for terrorist organisations.

For decades, non-state actors have been trying to acquire the materials needed for a nuclear device, but whether this represents a realistic effort to build a bomb or whether it is merely a red herring to their opponents is not certain. Osama bin Laden, for example, has directly declared that he intends to use nuclear (and chemical) weapons only for deterrence purposes, but it remains to be seen how he and his colleagues will use such weapons in future.

In an effort to construct norms regarding terrorism, the international community has responded in two ways. Firstly, via what a constructivist such as Onuf (1989) refers to as speech acts. Secondly, by institutionalising these speech acts via, inter alia, UN conventions such as the International Convention for the Suppression of Acts of Nuclear Terrorism, which opened for signature on September 14, 2005 - one of the most recent norm institutionalisations of ideas vis-à-vis terrorism (UN, 2005).

The possibility of terrorist organisations acquiring and deploying nuclear weapons has a major impact on the IAEA. In October 2005, Mohamed ElBaradei, head of the IAEA, confirmed this in the UN Security Council. Referring to the major expansion of the IAEA in a short period, ElBaradei made specific reference to the Agency's security programme, the Plan of Activities to Protect against Nuclear Terrorism. The IAEA has identified four possible terrorist scenarios, namely the theft of nuclear weapons, nuclear material and radio-active materials, and sabotage of nuclear power plants, fuel cycle facilities and/or research reactors of any industry using these substances (IAEA, 2005b:1). Since 9/11, the IAEA has conducted more than 100 security field missions and globally trained more than 1500 individuals in measures relating to the prevention of nuclear and radiological terrorism. In the process, the Agency discovered illicit nuclear procurement networks (UN News Service, 31 October 2005). Transnational criminal networks undermine international norms with regard to nuclear weapons. Despite efforts to prevent and contain such criminal activities, illicit trafficking in low-enriched uranium, plutonium and highrisk dangerous radioactive material continues and can be a short cut to nuclear proliferation and to nuclear terrorism. In an effort to prevent this, the IAEA established an Illicit Trafficking Database (ITDB) in 1995, which monitors incidents of illicit trafficking and other unauthorised activities. Currently, 82 IAEA members report to the ITDB. In the period between 1 January 1993 and 31 December 2004, although hugely underreported, 662 incidents were confirmed as illicit activities. Of these, 196 incidents involved nuclear materials and 400 involved radioactive material. Evidence suggests an increase in these activities between 2003 and 2004. Most of these were mainly criminal acts such as possession, theft, smuggling and attempted illegal sales on the "black market" (IAEA, 2005d:1-2; 2005e:1-2). Some of these confirmed incidents occurred in Russia, Germany, the Czech Republic, Bulgaria, Kyrgyzstan, Georgia, Lithuania, Greece and France (NTI, 2004:1-2). 


\section{Conclusion}

This article presented a constructivist analysis of states' constructed meaning of nuclear weapons. As a major technological and industrial revolution - so far only eclipsed by the emerging digital revolution - nuclear weapons continue to evoke images of destruction, power and security (or the absence of these).

The article presented a historical overview of the development of normative innovations and institutionalisations vis-à-vis nuclear weapons. It distinguished four phases, with the present phase (since 9/11) characterised by major new constructions of inter-subjective realities, social facts, identities, norms, interests and rules. Another major characteristic of this phase is the US's unrivalled dominance as a norm entrepreneur, cascader and norm institutionaliser.

Furthermore, the article indicated how the construction of India, Pakistan, China, North Korea and the US's inter-subjective realities regarding nuclear weapons determine these states' norms, identities, interests and actions. Particular attention was paid to the US's construction of a "smoking gun" in Iraq before the US invaded Iraq in 2003. The US reluctantly and selectively accepts the normative constraints of International Law and organisations and continues to reinforce its legal exceptionalism in these matters.

Finally, we analysed rules pertaining to the trade in nuclear weapons. From the analysis, it appears that states construct specific regulative and constitutive rules to trade. These rules have consequences, such as providing stability and predictability, as well as the exclusion of non-state actors and the need for the construction of new norms pertaining to the role of these actors. A major inference drawn from this contribution is that the NPT is seriously threatened by the selective adherence to its norms and rules; the fact that not all nuclear states are signatory to the NPT; the emergence of new nuclear actors (such as non-state actors), and the US's unrivalled dominance in this area.

\section{References}

Albrecht, U. 2000. The changing global composition of armed forces and military technology: the trend towards informalization. In M. Kaldor (ed.), Global insecurity. restructuring the global military sector. Volume 3. Pinter: London.

Ba, A., \& Hoffmann, M.J. 2003. Making and remaking the world for IR 101: A resource for teaching social constructivism in introductory classes. International Studies Perspectives. 4: 15-33.

Barkin, J.S. 2003. Realist Constructivism. International Studies Review, 5(3): 325-342. 
Barnett, M. 2005. Social Constructivism. In J. Baylis \& S. Smith (eds.), The globalisation of world politics. An introduction to international relations. Oxford: Oxford University Press.

BBC World Online. 19 September 2005. Available at www.bbcworld.co.uk Accessed on November 5, 2005.

Bunn, M. \& Wier, A. 2005. Securing the bomb 2005. The new global imperatives. Cambridge, MA: John F. Kennedy School of Government Project on Managing the Atom.

University Press.

Calaprice, A. (ed.) 2005. The new quotable Einstein. Princeton: Princeton

Chayes, A. \& Handler Chayes, A. 1993. On compliance. International Organization, 47(2): 175-205.

Cox, M. 1998. New China: new Cold War. In K. Booth (ed.), Statecraft and security. The Cold War and beyond. Cambridge: Cambridge University Press.

Dombrowksi, P. \& Payne, P.A. 2003. Global debate and the limits of the Bush doctrine. International Studies Perspectives, 4(4): 395-408.

Federation of American Scientists (FAS). 2002. Nuclear weapons. Available at www.fas.org/nuke/guide/india/nuke/. Accessed on April 23, 2007.

Farer, T. 2004. Toward an effective international legal order: from coexistence to convert? Cambridge Review of International Affairs, 17(2): 219-238.

Frederking, B., Artime, M. \& M. Sanchez Pagano. 2005. Interpreting September 11. International Politics, 42(1): 135-151.

Geeraerts, G. \& Jing, M. 2001. International relations theory in China. Global Society, 15(3):251-276.

Goldblat, J. (ed.) 1985. Non-proliferation: the why and the wherefore. London: Stockholm International Peace Research Institute (SIPRI).

Government of Britain. 2002. Iraq's weapons of mass destruction: the assessment of the British Government. Available at www.fco.gov.uk Accessed on November 5, 2005.

Guardian, The (London). 2005. MI5 unmasks covert arms programmes. Available at: www.guardian.co.uk Accessed on November 8, 2005. 
Halabi, Y. 2004. The expansion of global governance into the Third World: altruism, realism, or constructivism. International Studies Review, 6(1): 2148.

Howard, P. 2004. Why not invade North Korea? Threats, language games, and US foreign policy. International Studies Quarterly, 48(4): 805-828.

Howlett, D. 2005. Nuclear proliferation. In J. Baylis \& S Smith (eds.) The globalisation of world politics. An introduction to international relations. Oxford: Oxford University Press.

Human Rights Watch. 2005. Human Rights Watch Report 2005. Available at www.hrw.org. Accessed on November 5, 2005.

Hu, W. 2000. New Delhi's Nuclear Bomb: A Systemic Analysis. World Affairs, 16(1): 28-38.

IAEA (International Atomic Energy Agency). 2005a. Annual report for 2004. Vienna: IAEA.

IAEA. 2005b. Promoting nuclear security. Possible terrorist scenarios. Available at www.iaea.org. Accessed on November 8, 2005.

IAEA. 2005c. HEU nuclear material removed from Czech research reactor. Available at www.iaea.org. Accessed on November 9, 2005.

IAEA. 2005d. IAEA illicit trafficking database (ITDB). Available at Www.iaea.org. Accessed on November 7, 2005.

IAEA. 2005e. Illicit trafficking. Facts \& figures. Illicit nuclear trafficking statistics: January 1993-December 2004. Available at www.iaea.org. Accessed on November 7, 2005.

IISS (International Institute for Strategic Studies). 2005. Strategic Survey 2004/5. An evaluation and forecast of world affairs. London: Routledge.

Kegley, C.W. \& Raymond, G.A. 2003. Preventive war and the permissive normative order. International Studies Perspectives, 4(4): 385-394.

Kegley, C.W. \& Wittkopf, E.R. 2004. World Politics. Trend and Transformation. Berkeley: Wadsworth.

Klare, T.K. \& Chandrani, Y. 1998. World Security: Challenges for a new century. New York: St Martin’s Press. 
Koizumi, J. 2004. Address at the Nagasaki Memorial Service for the Nagasaki Peace Ceremony. August 9, 2004. Available at www.kantai.go.jp. Accessed on November 7, 2005.

Kractochwil, F.V. 1989. Rules, norms and decisions on the conditioning and legal reasoning in international relations and domestic affairs. Cambridge: Cambridge University Press.

Largio, D. 2004. 21 rationales for war. Foreign Policy, September/October 2004, available at www.foreignpolicy.com. Accessed on November 7, 2005.

MOFA (Ministry of Foreign Affairs of Japan). 2004. Japan's disarmament and non-proliferation policy. April 2004. Available at www.mofa.go.jp. Accessed on November 7, 2005.

MOFA. 2005a. On the three non-nuclear principles. Available at www.mofa.go.jp. Accessed on November 7, 2005.

MOFA. 2005b. Renewed determination towards the total elimination of nuclear weapons $\left(60^{\text {th }}\right.$ General Assembly 2005). Available at www.mofa.go.jp. Accessed on November 9, 2005.

Mutimer, D. 2000. The weapons state: Proliferation and the framing of security. Boulder, Co: Lynne Rienner Publishers.

Newnham, R.E. 2004. “Nukes for sale cheap?” Purchasing peace with North Korea. International Studies Perspectives, 5(2): 164-178.

NTI (Nuclear Threat Initiative). 2004. Incidents involving HEU (high enriched uranium) and $\mathrm{Pu}$ (plutonium) confirmed by the ITDB, 1993-2004. Available at www.nti.org. Accessed on November 7, 2005.

Onuf, N. 1989. World of our making. Rules and rule in social theory and international relations. Columbia: University of North Carolina Press. Avebury.

Pogany, I. (ed.) 1987. Nuclear weapons and International Law. Aldershot:

Regan, G. 2004. Picking the bones: Reclaiming the past from the politicians. Edinburgh: Mainstream Publishing Company.

Russett B., Starr, H. \& D.Kinsella. 2006. World politics. The menu for choice. London; Thomson Wadsworth.

Thomas, R.G.C. 2002. The shifting landscape of Indian foreign policy. In S.W. Hook (ed.), Comparative foreign policy. Adaptation strategies of the great and emerging powers. Upper Saddle River, New Jersey: Prentice Hall. 
UN News Service (New York). 2005. UN Nuclear watchdog reviews antiterrorism action, verification in general report, 31 October.

UN (United Nations). 2002. Report of the Policy Working Group on the United Nations and terrorism. Available at http://daccessdds.un.org. Accessed on November 5, 2005.

United Nations. 2005. International Convention for the Suppression of Acts of Nuclear Terrorism. Available at www.untreaty.un.org. Accessed on November 5, 2005.

Vagts, D.F. 2001. Hegemonic International Law. The American Journal of International Law, 94(4): 843-848.

Van Vuuren, R. 2003. Nuclear non-proliferation: The South African experience in global context. Unpublished M A thesis. Pretoria: University of South Africa (UNISA).

Walker, W. 2004. Weapons of mass destruction and international order. Adelphi Paper 370. London: International Institute for Strategic Studies (IISS).

Wendt, A. 1992 Anarchy is what states make of it: the social construction of power politics. International Organization, 46(2); 391-425.

Wendt, A. 1994. Collective identity formation and the international state. The American Political Science Review, 88(2): 384-396.

Wendt, A. 1995. Constructing international politics. International Security, 20(1): 71-81.

WNA (World Nuclear Association). 2005. Reactors database. Available at www.world-nuclear.org. Accessed on November 7, 2005.

Widmaier, W.W. 2004. The social construction of the 'Impossible Trinity': the intersubjective bases of monetary cooperation. International Studies Quarterly, 48(2): 433-453.

Wirtz, J.J. 2003. Whatever happened to arms control? International Studies Review, 5(3): 390-392.

Wittkopf, E.R., Kegley, C.W. \& J.M. Scott. 2003. American foreign policy: patterns and process. California: Wadsworth.

Zehfuss, M. 2002. Constructivism in international relations. The politics of reality. Cambridge: Cambridge University Press. 
Zhang, Y. 2001. System, empire and state in Chinese international relations. Review of International Studies, 27 (5):43-63.

${ }^{1}$ For an exposition and application of and critique on constructivism, refer to, amongst others, Barkin (2003:325-342), Widmaier (2004:433-453) and Zehfuss (2002).

${ }^{2}$ This is taken from the official website of the government of North Korea. Available at: www.korea-dpr.com and accessed on November 5, 2005.

${ }^{3}$ For the debate on the legality, or not, of the 2003 Iraq invasion, refer to, inter alia, IISS (2005:54-68). 